\title{
The Challenges of Overcoming Post-traumatic Stress Disorder in Toni Morrison's Sula and Home
}

\author{
Selay Marius KOUASSI \\ Peleforo Gon Coulibaly University, Côte d'Ivoire \\ Email: lebonselay@gmail.com
}

\begin{abstract}
From a psychoanalytical perspective based on the works of Judith Herman, and on the basis of close reading, this paper explores the challenges and the possibilities to recover from post-traumatic stress disorder in Toni Morrison's Sula and Home. It exposes, on one hand, the obstacles African American veterans with chronic war-induced post-traumatic stress disorder face as they try to rebuild their shattered selves. On the other hand, it sheds light on the tools these damaged veterans resort to, in order to reconcile with their traumatic memories and come to terms with the haunting presence in their lives. Sula and home offer ground to discuss topics such as the healing of post-war trauma and the assistance provided to soldiers diagnosed with posttraumatic stress disorder while they raise questions about the provision of material and emotional support to war veterans in American society.
\end{abstract}

Keywords- Healing, Post-traumatic, Trauma, Veterans, War.

\section{INTRODUCTION}

Far from being first-hand war narratives, Sula ${ }^{1}$ and Home ${ }^{2}$ are an exploration of the traumatic experience of Black soldiers, veterans of both World War I and the Korean War, as they journey towards healing.

Sula and Home respectively narrate the experiences of Shadrack and Frank Money who served time in armed military combat and who came home only to fight more battles, which are different from the ones they faced on the battlefields. These novels depict the recuperative process of these soldiers suffering from post-traumatic stress disorder ${ }^{3}$ and the challenges they face in gathering

\footnotetext{
${ }^{1}$ Morrison, Toni. Sula. New York: Knopf, 1973.

${ }^{2}$ Morris on, Toni. Home. New York: Knopf, 2012.

${ }^{3}$ Further references to posttraumatic stress disorder will appear in the text with the abbreviation PTSD, which should be understood, in the context of the present study, as a psychological condition connected to the trauma of battle.
}

pieces of their shattered lives to once again become whole individuals.

This paper, which presents Sula and Home from a psychoanalytical pers pective based on the works of Judith Herman, focuses on the following central hypothesis: there are strong internal and external forces threatening the process of working through the traumatic memories, and though the recovery process discussed herein may be difficult at best and impossible at worst, survivors could tap into the enormous potential of social bonds and communal support to regain their wholeness. This paper seeks to answer the following question: what challenges do African-Americans soldiers with chronic war-induced PTSD face as they try to overcome their trauma and what could be the possible ways for them to reconnect with their lost selves?

The discussion in this paper starts with conceptual clarifications so as to help the reader understand the rationale behind the choice of the theory underpinning this research. The second section of this paper analyses the challenges war veterans are facing as they try to overcome PTSD, while the third one puts the spotlight on the key elements that war veterans suffering from PTSD resort to in order to overcome the trauma and restore their wholeness. There too, the regenerative potentiality that both black individuals and the African American community possesses is highlighted.

\section{CONCEPTUAL CLARIFICATIONS}

Broadly speaking, Psychoanalysis is a theory of individual human behavior and experience which seeks to explain the complex relationship between the body and the mind and furthers the understanding of the role of emotions in medical illness and health. In other words, Psychoanalysis is a method of understanding mental functioning and which rests on the idea that there are many unconscious factors that have the potential to produce disturbances of personality traits, including disturbances in self-esteem and difficulty in relating to others. 
Sigmund Freud, who coined the term "psychoanalysis" in 1896 also worked on developing its main principles, objectives and methodology. Over the years, pshychoanalysis has been enriched by many contributions, including Judith Herman's Trauma Theory ${ }^{4}$, which outlines new concepts for understanding, defining, and treating of trauma, especially PTSD.

As mentioned earlier, the present study attempts to read Sula and Home from a psychoanalytical perspective based on the works of Judith Herman. Why then is Herman's trauma theory relevant to this study? In fact, her concept of trauma recovery, particularly PTSD, is built around a triphasic model of treatment (establishing safety remembrance and mourning -and reconnection with ordinary life) which reflects Morrison's characters' journey as they progress towards healing and wholeness. It is with this in mind that the reader may understand the rationale behind this research and both the recovery tools and the restorative journeys of Shadrack and Frank discussed herein.

\section{CHALLENGES OF RECOVERING FROM POST-TRAUMATIC STRESS DISORDER}

Throughout the selected novels, war veterans are facing many challenges as they try to overcome PTSD. These challenges encompasses inner struggles, inadequate health care and the racially-prejudiced environment that draws them downwards.

\section{Fighting Inner Battles}

Usually, when people talk about war injuries, they think of physical injuries; they hardly think of psychological scars. In fact, over the years, war-related physical injuries have been publicized by both the media and movie industries whereas war-induced mental scars have largely gone unreported. As a result, many veterans returning from war, wounded, but not with obvious physical injuries, were not provided with adequate treatment and were left alone to fight a war that was beyond their capacity to deal with. And too often, war veterans try to battle or resolve their inner conflict and escape reality, or relieve stress and ease emotional discomfort by consistently ignoring or suppressing the haunting past instead of confronting it. As a result, the past they have long repressed absorbs them and produces a kind of breach in their mind. This situation is reflected in Morrison's Sula and Home.

\footnotetext{
${ }^{4}$ Judith Herman is a high-profile trauma expert whose book Trauma and Recovery: The Aftermath of Violence-from Domestic Abuse to Political Terror, published in 1992 is still considered an essential work in the field of traumatology.
}

In Home, Frank shows sleep disturbances, including sleep-related movement disorders, insomnia, parasomnias and horrible nightmares ${ }^{5}$ that constantly invade his spirit. Even awake, his vision is tainted with temporal colorblindness: "[a]ll color disappeared and the world became a black-and-white movie screen" (Home, 23). The Korean War veteran's life is filled with distressing flashbacks of the war and horrifying images of mutilation and dismemberment, like that of the little girl with slanted eyes, that of the half-faced boy calling for his mother or that of the boy pushing his entrails back inside his torn body. These images haunt him often:

[...] when he was alone and sober, whatever the surroundings, he saw a boy pushing his entrails back in, holding them in his palms like a fortune-teller's globe shattering with bad news; or he heard a boy with only the bottom half of his face intact, the lips calling mama. And he was stepping over them, around them, to stay alive, to keep his own face from dis solving, his own colorful guts under that ohso-thin sheet of flesh. Against the black and white of the winter landscape, blood red took center stage. They never went away, these pictures. (Home, 20)

With a chaotic memory, Frank is wandering and roaming the streets in Seattle, living a disoriented and empty existence exacerbated by the lost of his best two friends, his "homeboys", Mike and Stuff, in Korea."Long after he'd been discharged, [Frank is still tortured by hallucinations of this tragic experience] he would see Stuff's profile in a car stopped in traffic until the heart jump of sorrow announced his mistake. Abrupt, unregulated memories put a watery shine in his eyes. For months, only alcohol dispersed his best friends, the hovering dead he could no longer hear, talk to, or laugh with" (Home, 99).

As the reader may notice Frank attempts to block out emotional distress and keep horrifying hallucinations at bay by consuming narcotics and alcohol. Frank uses alcohol and drugs to escape reality and reduce symptoms of stress. The harmful impact of these substances upon his health becomes more evident. They contributed to "poor

\footnotetext{
${ }^{5}$ These aspects of sleep diffciculties faced by veterans with PTSD are described in more details by Roszell and al. See Roszell DK, McFall ME, Malas KL. Frequency of symptoms and concurrent psychiatric disorder in Vietnam veterans with chronic PTSD. Hosp Community Psychiatry. 1991 Mar; 42 (3):293-6.
} 
clinical outcomes including [...] increased suicidiary and depression",6.

Alcohol and drugs are much valued among veterans with chronic war-induced PTSD; these substances are considered to be a beacon in times of stress. Yet the respite from reality and the relief they provide are actually short-lived and make mental wellness worse in the long run, as they can never put those ghosts of the past to rest so easily. In Home, these intrusive memories take possession of the Korean War veteran Frank Money, and as the narrator mentions: "They never went away these pictures"' (Home, 20).

Likewise, Shadrack, in Sula, has to deal with intrusive nightmares and hallucinations provoked by his traumatic experience of World War I, in 1917, in France. Even long after he had been discharged Shadrack is scared of possible dismemberment ${ }^{7}$. When he woke up at the hospital, lying in his bed, he looked at his own hands in a very strange way; he was frightened by his own hands as he believed his fingers could "grow in higgledy-piggledy fashion like Jack's beanstalk" (Sula, 9) or fuse into "a permanent entanglement with his shoelaces" (13). Shadrack feels relieved when he realizes that his hands were firmly attached to his wrist and that he ran no risk of having them detach from his body as was the case of the soldier whose head was blown off but who still kept running. World War I ended long ago, but his trauma didn't.

Even within the premises of the hospital, Shadrack felt unsecure and his strong feeling of chaos grew immoderately. He perceived the hospital yard and rooms as a battlefield. It is only the balanced triangles in the compartment food tray that "reassured [him] that the white, the red and the brown would stay where they were [and] would not explode or burst forth from their restricted zones" (Sula, 8).

Shadrack's life is full with hallucinations which makes his existence problematic. He tries to escape the trap of his daunting war recollections and to fix his unstable mental and feel safe by consuming alcohol and narcotics, where Mona Lisa Shultz and Louise Haywould prescribe the 'Exposure Therapy' ${ }^{8}$ based on the sharing of the

${ }^{6}$ Germain A, Nielsen TA. Sleep pathophysiology in posttraumatic stress disorder and idiopathic nightmare sufferers. Biol Psychiatry. 2003 Nov 15; 54(10):1092-8.

7 The following section looks closely at how the war veterans, especially Blacks were provided medical treatment.

${ }^{8}$ Exposure Therapy is a technique in behavior therapy which is thought to help patients treat and overcome their anxiety or distress. It helps individuals establish a coherent life narrative in which to contextualize traumatic narrative of the traumatic experience. Storytelling, as one of the main components of the Exposure Therapy "stimulates the original embodied experience of traumatic events for soldiers so that they can connect to specific details of their memories [... "," . As Skip Rizzo acknowledges, this therapy helps war veterans with chronic war-induced PTSD to engage in cognitive restructuring by telling the story of their experience ${ }^{10}$.

Weeks after being discharged from military hospital, Shadrack and Frank alike found themselves in a situation where they were incapable of confronting their past and telling their stories in relation with the horrors of war. The strategies (the consumption of alcohol and narcotics, and forcing down feelings of anxiety and distress) which they adopted in fighting the devastating inner battle proved ineffective, as many repressed emotions and excruciating memories surfaced again and again, leaving them extremely disturbed.

In addition to the aforementioned inner battle threatening the process of working through the traumatic memories, there are also external factors and forces such as the inadequate medical treatment and the challenging social environment that are at work throughout the novel and that threaten the recovery process.

\section{Inadequate Medical Treatment}

experiences. This therapy mainly consists in using imagery to imagine past traumatic events and conceive present circumstances that remind them. It involves exposing the target patient to the anxiety source or its context without the intention to cause any danger. The 'Exposure Therapy', is extensively discussed in Mona Lisa Shultz \& Louise Hay's Heal Your Mind: Your Prescription for Wholeness, Through Medicine, Affirmations, and Intuition, published by Hay House in 2016.

${ }^{9}$ Kent Bye, PTSD Exposure Therapy in VR: Importance of Storytelling \& Emotional Presence in Healing Trauma, https://www.roadtovr.com/ptsd-exposure-therapy-vrimportance-storytelling-emotional-presence-healingtrauma. Published on August 26, 2017. (Accessed June 14, 2018).

${ }^{10}$ Skip Rizzo, a high-profile psychiatrist and an internationally known expert in Mind-Body Medecine, currently heads the Medical Virtual Reality Research Group at USC's Institute for Creative Technologies. He is He has been on the forefront of using virtual reality to treat soldiers with posttraumatic stress disorder with virtual exposure therapy. Rizzo argues that a key component of healing from PTSD is if the patient is able to connect to the underlying emotions of the experience while sharing the narrative of his/her experience, and that this can unlock a cascade of healing effects. 
On 2017 Veterans' Day held on Saturday 11 November, Equal Justice Initiative ${ }^{11}$ released a report ${ }^{12}$ that acknowledges that unlike their white counterparts, African American veterans, especially the mentally ill ones, did not receive the appropriate medical care when they were hospitalized or when they were discharged from the army and returned to civilian life. Yet mental illness does not discriminate.

In Sula, the reader learns that Frank, the Korean War veteran, spent two years in a military hospital from which he was then discharged owing to lack of beds. Frank did not receive adequate medical treatment at that hospital and was released by doctors who granted himpermission to go home while they were fully aware that the war veteran was extremely disturbed. Doctors just let him know that he would get better soon. They informed him that the mental illness "would leave in time [and] assured him it would pass. Just stay away from alcohol, they said" (Home, 18). In fact, Shadrack had to vacate the bed for the medical staff to welcome a white patient.

In his Op-ed Black Veterans Treated as 'Second-Class Citizens,' Even Today, published in The Baltimore Sun, Dr. Adam M. Robinson, the first African American surgeon general of the U.S. Navy and Director of the VA Maryland Health Care System criticizes the unfair treatment of African American veterans: "[They] endure and survive the rigors of military service only to return home and be treated like second class citizens unworthy of even the most basic rights. A veteran suffering any kind of urgent medical condition deserves empathy, compassion and treatment [...]"13

On leaving the hospital, Shadrack felt disoriented and was extremely scared of people he saw in the streets, even the people he knew. He saw them as mere "paper figures that flex in the breeze" (Sula, 10). Both Shadrack and Frank really needed help and psychological support at the time they were discharged as they were absorbed by the traumatic memories of the war and suffered from urgent mental health condition that should have guaranteed them a ticket to stay at psychiatric hospital.

\footnotetext{
${ }^{11}$ Equal Justice Initiative is a private, nonprofit organization based in Alabama that confronts racial injustice, advocates for equality, and creates hope for marginalized communities.

12 See the full report "Lynching in America: Targeting Black Veterans, " at :http://eji.org/reports/online/lynchingin-america-targeting-black-veterans (accessed July 25, 2018).

${ }^{13}$ Adam M. Robinson. Black Veterans Treated as 'SecondClass Citizens,' Even Today. Available at:

https://www.baltimores un.com/news/opinion/oped/bs -edop-0115-black-veterans-20180111-story.html. Published on January 14, 2018. (Accessed on June 17, 2018).
}

In Morrison's portrayal of African American veterans with chronic war-induced PTSD, mental distress is not only associated to the horrors of war, but also to the inadequate medical treatment. She uses the journeys of Shadrack and Frank to show that, as for many African American veterans, it is the lack of proper health assistance which often negatively affects their mental wellness and shaped the rest of their lives.

Beyond the depiction of the PTSD symptoms African American veterans suffer from and the inadequate treatment they received at the hospitals, Morris on exposes the reception of these damaged heroes by a raciallyprejudiced society, where African American soldiers return, becoming themselves racial victims.Throughout the selected novels, the oppression that this society exerts on these veterans takes the form of both brutal physical and psychological violence.

\section{The Challenging Social Environment}

It is really hard for Shadrack and Frank to make the transition back to civilian life, as they face a society that does not help them adjust to non-military life. Neither Shadrack nor Frank were able to find a decent job to make both ends meet. Frank, for instance, "regularly lost the few odd jobs he'd managed to secure" (Home, 21), while on the other hand, Shadrack is described as "sell[ing] fish but, in winter, when the fish is harder to catch, he also does pick-up errands for small businesses, as "nobody would have him in or even near their homes" (Sula, 155). As a result, they were pushed deeper into depression and ended up in the streets.

While one can understand that it is difficult for both civilians and war veterans to secure a steady job in a situation compounded by soaring unemployment and poverty, it is difficult to admit, as Christopher de Santis points out, that African American veterans are "treated with the same humiliating disrespect as their fellow black civilians $[\ldots]^{\prime \prime 14}$

After the war, many black veterans returning home were greeted not with recognition of their civil rights but, instead, with hostility and discrimination. As Peter Baker puts it, in his article The Tragic, Forgotten History of Black Military Veterans: "In the years after the war, at least thirteen black veterans were lynched. Countless more survived beatings, shootings, and whippings. As E.J.I. staff examined these attacks in detail, they noticed

\footnotetext{
${ }^{14}$ De Santis Christopher, ed. 1995. Langston Hughes and the Chicago Defender: Essays on Race, Politics and Culture, 1942-1962. Urbana: Illinois UP. P.18.
} 
that, often, the only provocation was a black man's insistence on wearing his uniform in public" 15 .

In Home, Pastor Reverend Locke warns the Korean W ar veteran and makes it clear to him that the fact that African Americans have been risking their lives on the battlefield for America does not bring any significant social change to the situation of African Americans : "Well, you not the first by a long shot. An integrated army is integrated misery. You all go fight, come back, they treat you like dogs. Change that. They treat dogs better" (Home, 18).

Along his travels, Frank witnessed racial humiliation. For instance, he came across a black couple who got beaten for daring to order coffee from a white establishment. Frank, later on, became himself a target of this rampant racial discrimination; he experienced it when he is subject to a random search outside a shoe store.

In Sula, Shadrack, the World War I veteran, is arrested for vagrancy and intoxication, just after he was discharged from hospital. Actually, Shadrack felt dizzy and stumbled as if he were drunk. Instead of sending Shadrack back to hospital, he was sent to jail.

Morrison's depiction of the fate of African American veterans in Sula reflects a reality that happened during the pre-Civil Rights era; yet it continues today, as explained by General Adam M. Robinson, who brought into the limelight the recent murder of an African American military veteran that almost went unnoticed:

[...] the murder of African-American military veterans continues. Most recently, a federal jury awarded $\$ 10$ million to the family of an Oklahoma Army veteran who died in a Tulsa jail with a broken neck after he was tortured for 51 hours, begging for water and help. This Army veteran who served overseas was arrested in a hotel while having a mental breakdown after his wife left him, clearly suffering from an urgent mental health condition that should have warranted a trip to the closest emergency department instead of a jail. ${ }^{16}$

Adam Robinson acknowledges that despite the progress that has been made over the last five decades as regards the basic rights of African American veterans, the shameful treatment and humiliation of these soldiers returning from war continues and the advance of racism towards them is largely ignored. As he tries an investigation and a scientific explanation of the targeting of African American veterans, Robinson maintains that

15 Retrieved from:

https://www.newyorker.com/news/news-desk/the-tragicforgotten-his tory-of-black-military-veterans. Published on November 27, 2016. Accessed on March 18, 2018.

${ }^{16}$ Adam M. Robinson, Op.cit.
"[...] when they donned the uniform of their nation and fought to defend it, they challenged stereotypes about African Americans in ways that domestics and sharecroppers could not. That is why they were targeted so frequently.",17

The inner battle and the inadequate medical treatment added to the challenging social environment dominated by racial prejudices made it difficult to war veterans Shadrack and Frank to heal their psychological wounds.

\section{TOOLS FOR RECOVERING FROM POST TRAUMATIC STRESS DISORDER}

Recovering from Trauma, especially from PTSD is a complicated process. As Judith Herman explains: "Resolution of trauma is never final; recovery is never complete. The impact of the traumatic event continues to reverberate throughout the survivor's lifecycle" (Herman, 1992: 211). On the other hand, Herman acknowledges that while incomplete, recovery allows the survivor to overcome his trauma and to gradually engage a sense of control, to develop a feeling of safety within and among other and self and to engage in healthy and stable relationships.

It is with this in mind that the reader may understand the rationale behind this section and both the recovery tools and the restorative journeys (of Shadrack and Frank) discussed herein.

Despite the difficulties in healing completely the psychological wounds of war, Morris on's depiction of the journey of characters with chronic war-induced PTSD suggests and stresses the possibility of personal recovery through various methods that include love from caring persons, storytelling and support from the community.

\section{Caring Persons and Assistance From the Community}

Throughout Home, Love and assistance from caring persons is key to Frank's healing. In his voyage from trauma to self-discovery and recovery, Frank met with different persons, especially Lily, his Asian lover, whose affection and love were critical for his restoration. As he acknowledges himself, Lily makes him "want to be good enough for her" (Home, 69) and makes him feel safe and determined to confront his past: "Right then I decided to clean up. To hell with the dreams. I needed to make my homeboys proud. Be something other than a haunted, half-crazy drunk. So when I saw this woman at the cleaner's, I was wide open for her" (69, italics in original)

\footnotetext{
${ }^{17}$ Ibid.
} 
Lily almost succeeded in "changing [Frank]" (69) and making him feel safe ${ }^{18}$ and rely on her. Thanks to Lily's care, " $[\mathrm{t}] \mathrm{his}$ feeling of safety and goodwill, he knew, was exaggerated [...]" (118). As a result, during the few months Frank spent with Lily, he did not suffer from any intrusive nightmare or hallucination. He enjoyed a kind of respite he was happy with. As the narrator emphasizes, "his attachment to her was medicinal [...] Lily displaced his disorder, his rage and his shame" (107).

Frank's recuperative process would have not been possible without the tremendous support and the solidarity of some generous characters like Reverend Locke and Billy Watson who provided him with both the material and emotional assistance and gave him advice which he truly needed to rebuild his shattered self and reconstruct human connection. Reverend Lock, for instance, warns him about the possible obstacles he is likely to face in the North: "[...] you been in a desegregated army and maybe you think up North is way different from down South. Don't believe it and don't count on it. Custom is just as real as law and can be just as dangerous" (Home, 19).

The supportive social network that the community provided too, was pivotal in Frank's healing. Thus, Morrison emphasizes the power of the healing community and maintains that mending from psychological wounds can succeed with the full support and assistance of the community. It is, indeed, in the midst of this nurturing community that the damaged war veterans can eventually unleash the disturbing past and heal their fragmented selves.

The empathy that the community shows to war veterans helps them appease the disturbing past and gain stability ${ }^{19}$. Eminent PTSD experts, including Mary Harvey, Skip Rizzo and Judith Herman argue that empathy stands as an important step in building a proper

${ }^{18}$ For psychiatrist and trauma expert Judith Herman, establishing safety is the very first stage of the PTSD recovery process. During this stage, survivors shift their surroundings from that of unpredictable danger to reliable safety. Herman describes recovery from traumatic events as unfolding in three stages. The second stage includes the tasks of remembrance and mourning, while the third and last one encompasses reconnection with ordinary life. Herman stresses the fact that these stages are not followed exactly, nor are they linear.

${ }^{19}$ Herman argues that as the group shares mourning, it simultaneously fosters hope for new relationships. The group lends a kind of formality and ritual solemnity to individual grief and helps the survivor to pay homage to his lost and piece together his once shattered life, in the present. See Trauma and Recovery: The Aftermath of Violence--from Domestic Abuse to Political Terror, New York: Basic Books, 1992. P. 228. mourning process ${ }^{20}$; a phase where the survivors verbally tell the whole, in-depth story.

Storytelling, indeed, falls in the range of tools that help Shadrack and Frank heal from PTSD throughout Sula and Home.

\section{Storytelling and the Emphatic Listener}

In Sula and Home, it is only after having gained the confidence of their fellow beings and after having secured their trust that war veterans, suffering from PTSD, tell their stories. Again, it is the community's empathy shown to them that allowed veterans to open up to their community members.

Once he feels safe, Frank confesses he needs to face the truth about his past and recover his wholeness. He tells his interlocutor, an unnamed scribe: "I have to say something to you right now. I have to tell the whole truth. I lied to you and lied to me. I hid it from you because I hid it from me. I felt so proud grieving over my dead friends" (133, italics in original). Frank admits he has long repressed his past and that time has come for him to open up about those traumatic memories. But he challenges the scribe's capacity to properly listen ${ }^{21}$, record and tell his traumatic experiences.

Herman observes that a good listener, with active listening skills, is essential in caring for trauma survivors as this kind of listening encourages the survivor to put the trauma into the appropriate words and narrative forms which are essential to healing ${ }^{22}$.

Throughout the selected novels, storytelling becomes a kind of catharsis which helps Shadrack and Frank cure their emotional and psychological wounds. As the veterans remember their traumatic past and narrate

${ }^{20}$ The remembrance and mourning is considered by Judith Herman as the second stage of the PTSD recovery process which she described in three stages, while other trauma experts identify five and some eight. This study focusses on Herman's three.

${ }^{21}$ See Dori Laub. Bearing witness or the vicissitudes of listening. In S. Felman \& D. Laub (Eds.), Testimony: Crises of Witnessing in Literature, Psychoanalysis, and History. New York \& London: Routledge, 1992. P.58.Dori Laub argues that the Korean war veteran may has good reasons to suspect his listener's ability to render his traumatic experiences in words, as the listener has to feel the survivor's defeat, pain and silences and know his victories from within in order to assume the form of testimony.

22 In Trauma and Recovery: The Aftermath of Violence-from Domestic Abuse to Political Terror, Herman maintains that the emphatic listener is crucial in the process of the survivor's reconstruction of a sense of self. For her, it is the presence of a careful listener willing to bear witness and to assist the survivor that allows the wounded self to repair and strengthen. 
extreme and unspeakable situations, the reader realises that they escape the numbness and the ghostly state in which they were absorbed and begin to reveal some signs of recovery.Frank, for instance, "realized that those memories, powerful as they were, did not crush him anymore or throw him into paralyzing despair. He could recall every detail, every sorrow, without needing alcohol to steady him" (Home, 100). On the other hand, Shadrack shows some signs of transformation: his war remembrances fade away and he finally understands he cannot control life or death (Sula, 156). Sula's demise affects him deeply and brings him close to tears. For the first time, the veteran freely expresses his feeling as does Frank in Home, in Lotus, when his sister Cee tells him that she cannot have a baby. The reader realizes that Frank can acknowledge pain and can finally cry, which he has not done since he was a child. His final psychological recovery happens when he confronts his past and tells his story.

As Kristin Boudreau puts it: "suffering can heal and humanize, provided that one can reorganize the painful events of the past and retell them in one's own language",23. Likewise, Herman claims that it is generally when trauma survivors are determined to narrate their painful memories and to reshape them that they begin to show some capacity to integrate those memories into their life story ${ }^{24}$.

The closing sections of both Sula and Home make evident the in-depth transformation that Shadrack and Frank have undergone and which lead them to socially reconnect with the community. In this regards, it could be argued that these novels suggest that recovery from trauma is usually possible despite the many obstacles that may stand on the road to psychological restoration. It is also undeniable that storytelling features prominently in the process for recovering from trauma.

\section{CONCLUSION}

This paper looked at Morrison's Sula and Home from a psychoanalytical angle, especially through the lenses of Judith Herman's trauma theory, in order to decipher, on one hand, the challenges faced by African American veterans with chronic war-induced PTSD and explore, on the other hand, possible ways of healing.

The lives of Morrison's damaged characters, Shadrack and Frank, respectively World War I and Korean War veterans are full with hallucinations which make their

\footnotetext{
${ }^{23}$ Kristin Boudreau. Pain and the Unmaking of Self in Toni Morrison's Beloved [Fragment]. Toni Morrison: Beloved. Columbia Critical Guides. Ed. C. Plaza. New York: Columbia UP.1998. P. 105.

${ }^{24}$ Herman, op.cit., P.84.
}

existence problematic. The challenges these war veterans faced as they try to reconcile with their traumatic memories and come to terms with their haunting presence in their lives include, but are not restricted to, the devastating inner struggles, the inadequate medical treatment and eventually the racialized social environment. Throughout the selected novels, the oppression that the American society exerts on these veterans takes the form of both brutal physical and psychological violence that lead them to turn to the consumption of alcohol and drugs to force down feelings of anxiety and distress. All those methods proved ineffective, as many repressed emotions and excruciating memories surfaced again and again, leaving them extremely disturbed.

As they started their journeys towards healing, Morrison's mad characters were unable to confront their past and tell their stories in relation with the horrors of war. Yet, at the end of both Sula and Home the reader discovers that they have reconstructed their shattered selves, at least, partially.

It is both the love and care of relatives and the empathy and support that the community shows to war veterans that help them appease the disturbing past, reconstruct their shattered selves and gain stability. The remembrance and mourning process during which the survivors verbally tell their whole and in-depth story also falls in the range of tools that help war veterans restore their wholeness, in Sula and Home. Throughout these fictional works, Morrison suggests and stresses the possibility of personal recovery through the methods aforementioned, emphasizing the fact that total recovery and wholeness is linked to the power of the healing community.

\section{REFERENCES}

[1] Baker, P. (2016). The Tragic, Forgotten History of Black Military Veterans. Available at: https://www.newyorker.com/news/news-desk/thetragic-forgotten-history-of-black-military-veterans. (Accessed on March 18, 2018).

[2] Boudreau, K. (1998). Pain and the Unmaking of Self in Toni Morrison's Beloved. Toni Morrison: Beloved. Ed. Columbia UP. New York.

[3] Christopher, D. Ed. (1995). Langston Hughes and the Chicago Defender: Essays on Race, Politics and Culture, 1942-1962. Urbana: Illinois UP.

[4] Equal Justice Initiative. (2017). Lynching in America: Targeting Black Veterans. Available at: http://eji.org/reports/online/lynching-in-americatargeting-black-veterans. (Accessed July 25, 2018).

[5] Germain, A.N. (2003). Sleep Pathophysiology in Posttraumatic Stress Disorder and Idiopathic 
Nightmare Sufferers. Biol Psychiatry, 54(10):10928.

[6] Herman. J. (1992). Trauma and Recovery: The Aftermath of Violence--From Domestic Abuse to Political Terror, New York: Basic Books.

[7] Kent, B. PTSD Exposure Therapy in Virtual Reality: Importance of Storytelling \& Emotional Presence in Healing Trauma. Available at: https://www.roadtovr.com/ptsd-exposure-therapyvr-importance-storytelling-emotional-presencehealing-trauma. (Accessed June 14, 2018).

[8] Laub, D. (1992). Bearing witness or the vicissitudes of listening. Testimony: Crises of Witnessing in Literature, Psychoanalysis, and History. Eds. Felman \& D. Laub. New York \& London: Routledge.

[9] Morrison, T. (1973). Sula. New York: Knopf, 1973.

[10] ---o-. (2012) Home. New York: Knopf.

[11] Rizzo, A.S and al. (2014). Virtual Reality Exposure Therapy for Combat-Related Posttraumatic Stress Disorder, 47 (7): 31-37.

[12] Robinson, A. (2018). Black Veterans Treated as 'Second-Class Citizens,' Even Today. Available at: https://www.baltimoresun.com/news/opinion/oped/b s-ed-op-0115-black-veterans-20180111-story.html. (Accessed on June 17, 2018).

[13] Roszell, D.K. and al. (1991). Frequency of Symptoms and Concurrent Psychiatric Disorder in Vietnam Veterans with Chronic PTSD. Hosp Community Psychiatry. Vol-42 (3): 293-6.

[14] Shultz L.M. \& Hay, L. (2016). Heal Your Mind: Your Prescription for Wholeness, Through Medicine, Affirmations, and Intuition. New York: Hay House. 